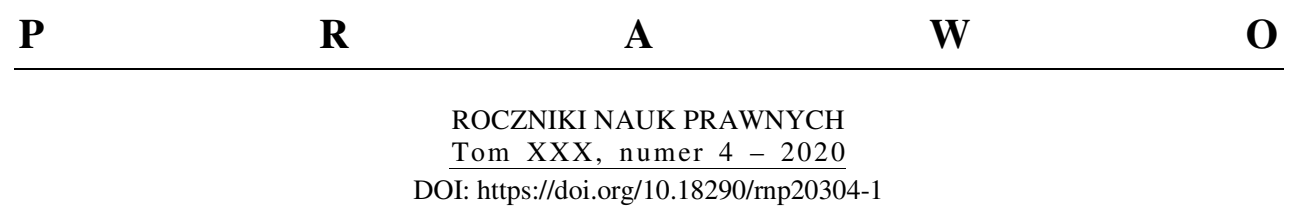

DAMIAN BARA

\title{
PROCEDURA POSTĘPOWANIA POLUBOWNEGO W WARUNKACH KONTRAKTOWYCH FIDIC
}

WPROWADZENIE

Analizując treść oraz postanowienia Warunków Kontraktowych FIDIC z 1999 r. (dalej: FIDIC), w pierwszej kolejności należy podkreślić, że są one zgodne z zasadami związanymi z właściwym prowadzeniem procesu budowlanego niezależnie od tego, w jakim kraju jest prowadzona budowa. Okoliczność ta prowadzi do stanowiska, zgodnie z którym dostosowanie ich treści do prawodawstwa kraju, w którym prowadzone są roboty budowlane, nie powinno powodować większych trudności. Dlatego też Warunki te można uznać za jedyne w Polsce umowne standardy zrównoważonego sposobu prowadzenia robót budowlanych ${ }^{1}$.

FIDIC w swojej treści odnosi się nie tylko do standardów dotyczących realizacji inwestycji budowlanej, lecz zawiera także mechanizm pozwalający stronom realizującym kontrakt na rozwiązanie sporu bez konieczności angażowania czynnika państwowego, takiego jak sądy powszechne. Należy mieć na względzie, że warunki te same w sobie nie obowiązują w taki sposób, w jaki obowiązują przepisy prawa cywilnego. Warunki Kontraktowe FIDIC nabierają mocy wiążącej dopiero w momencie, w którym zostaną inkorporowane do łączącej strony umowy².

Dr DAMIAN BARA - asystent Katedry Negocjacji i Mediacji, Instytut Nauk Prawnych, Wydział Prawa, Prawa Kanonicznego i Administracji Katolickiego Uniwersytetu Lubelskiego Jana Pawła II, Al. Racławickie 14, 20-950 Lublin; e-mail: damian.bara@ kul.pl; ORCID: https://orcid.org/0000-0002-2082-2875.

${ }^{1}$ E. WiKTOROwSKA, Zgodność warunków kontraktowych FIDIC z prawem polskim, „Biuletyn Konsultant" 2010, nr 15, s. 10-11.

${ }^{2} \mathrm{H}$. WysocZAŃSKI, Prawo do zmiany oraz polecenie zmiany treści umowy o roboty budowlane w świetle warunków FIDIC, Warszawa: Wydawnictwo C.H. Beck 2017, s. 9-10. 
Niemniej należy podkreślić, że FIDIC zawdzięcza swoją popularność w zasadniczej mierze rozbudowanej procedurze polubownego rozwiązywania sporów. Zawiera relatywnie kompleksową regulację, która umożliwia stronom umowy pozasądowe rozwiązanie sporu. Regulacja ta zawarta jest m.in. w Subklauzulach 20.1 do 20.8 Księgi Czerwonej, Żółtej i Srebrnej Warunków Kontraktowych oraz w Subklauzulach 20.3 do 20.11 Księgi Złotej FIDIC. Zaznaczyć należy, że w przypadku, kiedy dojdzie do powstania sporu w ramach realizowanego kontraktu budowlanego, o jego wyniku (w przypadku stosowania mechanizmu rozwiązywania sporów przewidzianego przez FIDIC) nie będzie decydować brzmienie przepisów prawa znajdujących swoje zastosowanie do oceny postanowień danej umowy, lecz ustalony stan faktyczny i brzmienie zawartych przez strony postanowień. FIDIC jako standardową procedurę rozwiązania sporu przewiduje arbitraż, w tym w szczególności arbitraż międzynarodowy, którego zasadniczym celem jest poszukiwanie rozwiązań probiznesowych ${ }^{3}$.

Na uwagę zasługuje również fakt, zgodnie z którym w przypadku realizacji inwestycji rozbudowanych, w tym w szczególności inwestycji liniowych, takich jak drogi czy autostrady, ryzyko wystąpienia sporów wielomilionowych jest bardzo duże. Celem zobrazowania skali sporów mogących wystąpić w trakcie realizacji inwestycji budowlanych, na potrzeby niniejszego opracowania jako przykład zostaną przedstawione spory z udziałem Generalnej Dyrekcji Dróg Krajowych i Autostrad (dalej: GDDKiA). W 2016 r. Prokuratoria Generalna Skarbu Państwa reprezentująca GDDKiA prowadziła 418 postępowań sądowych, w których łączna wartość przedmiotu sporu wynosiła ok. 6,1 mld złotych, co spowodowało nagłe skierowanie do Sądu Okręgowego w Warszawie dużej liczby postępowań, w których wartość przedmiotu sporu niejednokrotnie wynosiła kilka milionów złotych ${ }^{4}$. Przywołana liczba sporów w wyodrębnionym i niewielkim obszarze szeroko rozumianego prawa budowlanego obrazuje skalę, jakiej muszą stawić czoła sądy powszechne. Dodatkowo należy mieć na względzie, że okoliczność ta wpływa także na terminowość rozwiązania sporu, co z kolei ma istotne znaczenie dla prawidłowej realizacji inwestycji budowlanej.

Zgodnie z klauzulą 20 FIDIC z 1999 r. strony chcące rozstrzygnąć zaistniały spór, w pierwszej kolejności mogą odwołać się do Inżyniera Kontraktu (który nota bene pełni funkcję quasi-mediatora). W przypadku nieosiągnięcia konsensusu kolejnym etapem jest skierowanie sporu do Komisji Rozjemczej ${ }^{5}$,

\footnotetext{
${ }^{3}$ Tamże, s. 7-8.

${ }^{4}$ Zob. http://www.rynekinfrastruktury.pl/wiadomosci/drogi/powrot-arbitrazu-do-rozstrzygania-sporow-w-budownictwie-drogowym-58784.html [dostęp: 20.08.2020].

${ }^{5}$ Zasadniczo celem Komisji Rozjemczej jest zapewnienie stronom kontraktu niezależnej i eksperckiej pomocy w sporach w takim czasie i sposób, który umożliwi jego rozwiązanie bez konieczności
} 
przed którą postępowanie stanowi etap poprzedzający arbitraż (również zaliczany do polubownych metod rozwiązywania sporów). Niemniej podkreślić należy, że ostateczny kształt procedury przewidzianej przez FIDIC uzależniony jest od woli stron, ponieważ strony w Warunkach Szczególnych mogą w pełni niezależny i swobodny sposób dostosować procedurę do swoich potrzeb czy też innych ważnych dla nich czynników zależnych od realizowanej inwestycji budowlanej. $\mathrm{Z}$ uwagi na okoliczność, że postępowanie arbitrażowe $\mathrm{w}$ świetle regulacji FIDIC poprzedza m.in. procedura przed Komisją Rozjemczą, zasadne będzie przedstawienie także tego postępowania, które również umożliwia stronom osiągnięcie konsensusu jeszcze na etapie przedarbitrażowym.

\section{ROSZCZENIE I JEGO ZNACZENIE W ŚWIETLE REGULACJI FIDIC}

Istotnym elementem stanowiącym niezbędny warunek wszczęcia procedury polubownego rozwiązywania sporu zarówno przed Inżynierem Kontraktu (o którym mowa w rozdziale III), jak i Komisją Rozjemczą czy też arbitrażem, jest dokładne określenie roszczenia i jego zgłoszenie w odpowiednim momencie. Roszczenie stanowi zatem element sine qua non procedury polubownego rozwiązania sporu w świetle regulacji FIDIC z 1999 r., który należy określić jako uprawnienie jednej ze stron danego stosunku prawnego (czyli umowy o roboty budowlane) do żądania stosownej rekompensaty za szkodę, którą strona ta poniosła w związku z realizacją zawartej umowy. Odpowiedzialność ta będzie zatem miała charakter roszczenia $\mathrm{z}$ tytułu niewykonania lub nienależytego wykonania zobowiązania, czyli ex contractu, jak i roszczenia będącego skutkiem czynu niedozwolonego, czyli ex delicto. Przenosząc powyższe na grunt umów o roboty budowlane i możliwych do wystąpienia roszczeń, podstawą do żądania przez wykonawcę umowy rekompensaty za doznaną szkodę majątkową, skutkującą np. wydłużeniem terminu realizacji inwestycji budowlanej przekładającą się na opóźnienie w otrzymaniu wynagrodzenia, może być np. opóźnienie w przekazaniu gruntu do realizacji inwestycji czy też prowadzenie nieprzewidzianych wcześniej prac archeologicznych. Wówczas roszczenie, stanowiące warunek procedury polubownego rozwiązania sporu w świetle regulacji FIDIC, powstaje w momencie wystąpienia szkody stanowiącej skutek danego zdarzenia ${ }^{6}$.

odwoływania się do arbitrażu. Zob. E. VINK, FIDIC and the use of Dispute. Adjudication Boards, „Biuletyn Konsultant” 2010, nr 15, s. 31.

${ }^{6}$ M. BAtDYGA, O Subklauzuli 20.1 Warunków Kontraktowych FIDIC, „Biuletyn Konsultant” 2013, nr 29, s. 11-12. 
Nadmienić należy, że roszczenie dotyczy tylko i wyłącznie ściśle określonego stosunku łączącego strony, co z kolei prowadzi do stanowiska, zgodnie z którym Subklauzula 20.1 nie odnosi się do przypadków, gdy w trakcie realizacji inwestycji budowlanej wystąpi konieczność realizacji dodatkowych prac budowlanych, wcześniej przez strony nieprzewidzianych, których nie obejmuje łącząca strony umowa o roboty budowlane. Niemniej, pomimo braku powiązania z umową, konieczność wykonania dodatkowych prac może wpłynąć na dalszy tok prac prowadzonych w związku z realizowaną inwestycją, co z kolei może przekładać się na terminowość jej realizacji. Stąd też przestój w pracach, który uniemożliwi dalszą realizację inwestycji budowlanej, będzie klasyfikowany jako szkoda, do której naprawienia zobowiązany będzie zamawiający. Będzie to zatem stanowić roszczenie zdefiniowane w Subklauzuli 20.1 Warunków Kontraktowych FIDIC z 1999 r. ${ }^{7}$

Zasadnicze znaczenie odgrywa czas, w jakim informacja o ewentualnym przedłużeniu czasu na realizację i ukończenie prowadzonych robót będzie zgłoszona do Inżyniera Kontraktu. Zgodnie z Subklauzulą 20.1 wykonawca winien możliwie najwcześniej przesłać powiadomienie o wystąpieniu okoliczności powodujących powstanie roszczenia. Powiadomienie powinno być przesłane najpóźniej w terminie 28 dni od momentu ${ }^{8}$, w którym Wykonawca dowiedział się lub powinien był dowiedzieć się o wystąpieniu zdarzenia wpływającego na terminowość realizacji inwestycji budowlanej. W przypadku niedochowania tego terminu czas na realizację inwestycji nie zostanie przedłużony. Zamawiający będzie zatem zwolniony z odpowiedzialności za takie roszczenie. Wskazany w przywołanej Subklauzuli 28-dniowy termin należy określić jako termin instrukcyjny. Jego celem jest zapewnienie możliwie najszybszego przekazania informacji o wystąpieniu jakichkolwiek czynników wpływających na terminowość realizacji inwestycji budowlanej, co z kolei przekłada się na możliwość, a nawet konieczność przedłużenia czasu trwania zawartej pomiędzy stronami umowy czy zapłaty dodatkowego wynagrodzenia, które nie było przedmiotem umowy. Ubocznie należy nadmienić, że niedotrzymanie przez Wykonawcę 28-dniowego terminu nie może wiązać się dla niego z negatywnymi sankcjami,

\footnotetext{
${ }^{7}$ Tamże, s. 12.

${ }^{8}$ Część przedstawicieli doktryny uważa, że 28-dniowego terminu na zgłoszenie roszczenia nie należy utożsamiać z terminem przedawnienia, który jest regulowany przez przepisy kodeksu cywilnego. Zob. A. OLSZEWSKI, Kontraktowe procedury rozwiazywania sporów w umowach o roboty budowlane opartych na wzorcach umownych FIDIC $-w$ świetle prawa polskiego, „Radca Prawny" 2010, nr 2, s. 67.
} 
w postaci chociażby odmowy przedłużenia terminu na realizację prac czy też odmowy zapłaty dodatkowego wynagrodzenia 9 .

Po przedłożeniu we wskazanym powyżej terminie roszczenia, istotną rolę odgrywał będzie Inżynier Kontraktu, który w terminie 42 dni od dnia otrzymania zgłoszonego przez Wykonawcę roszczenia lub dalszych informacji może zatwierdzić roszczenie bądź je odrzucić, jednocześnie wskazując przyczyny odrzucenia. Ponadto, celem pełnego wyjaśnienia sprawy, Inżynier może także zażądać od Wykonawcy dalszych informacji odnośnie do zgłoszonego roszczenia. Nadmienić należy, że oparciem postępowania Inżyniera Kontraktu będzie Subklauzula 3.5 Warunków Kontraktowych FIDIC z 1999 r., tj. określenia, na podstawie której uzgodnione zostanie przedłużenie czasu na ukończenie robót zgodnie z Subklauzulą 8.4, czy też uzgodnienie dodatkowej płatności, jeżeli Wykonawca jest do niej upoważniony. Regulacja zawarta w Subklauzuli 20.1 odnosząca się do roszczenia oraz czasu na jego zgłoszenie do Inżyniera Kontraktu stanowi regulację dodatkową w stosunku do pozostałych subklauzul Warunków Kontraktowych FIDIC. W przypadku, gdy wykonawca nie zastosuje się np. do Subklauzuli 20.1. w odniesieniu do roszczenia i terminu jego zgłoszenia, wówczas przedłużenie czasu na dodatkowe prace czy też przyznanie dodatkowej płatności będzie uwzględniało zakres, w jakim niezastosowanie się

\footnotetext{
${ }^{9}$ Dokonując analizy charakteru prawnego 28-dniowego terminu na zgłoszenie roszczenia, należy zwrócić uwagę na dwa stanowiska w tym zakresie. Początkowo orzecznictwo sądów wskazywało, że upływ tego terminu powodował wygaśnięcie roszczenia przysługującego Wykonawcy. Takie stanowisko znajduje swoje odzwierciedlenie m.in. w Uchwale składu 7 sędziów Sądu Najwyższego z dnia 19 maja 1969 r., sygn. akt III CZP 5/68. Sąd Najwyższy wskazał w niej, że oprócz istniejących terminów przedawnienia uregulowanych w przepisach k.c., istnieją także inne terminy, których upływ prowadzi do powstania odmiennych i surowszych skutków od tych przewidzianych w przepisach prawa dotyczących przedawnienia roszczeń. Terminy te nie mogą być zaliczane do terminów przedawnienia, a ich cechą charakterystyczną jest wygaśnięcie roszczenia po ich upływie. Na kanwie przywołanej sprawy roszczenie powoda objęte przedmiotowym pozwem wygasło z uwagi na fakt, że powód nie spełnił obowiązku i nie zawiadomił w terminie 28 dni Inżyniera o roszczeniu. Zobowiązanie zachowania terminu wynikało m.in. z zawartej pomiędzy stronami umowy o roboty budowlane oraz stanowiącymi do niej załącznik, Warunkami Kontraktowymi dla robót inżynieryjno-budowlanych projektowanych przez Zamawiającego. Zob. Uchwała składu 7 sędziów Sądu Najwyższego z dnia 19 maja 1969 r., sygn. akt III CZP 5/68, OSNC 1970, nr 7-8, poz. 117; wyrok Sądu Okręgowego w Toruniu z dnia 12 października 2016 r., sygn. akt VI GC 99/16, LEX nr 1026. Z kolei aktualna linia orzecznicza stoi w opozycji do powyższego stanowiska Sądu Najwyższego. Zgodnie z prawomocnym Wyrokiem Sądu Okręgowego w Warszawie nałożenie na Wykonawcę ograniczonego do 28 dni terminu niosącego ze sobą poważniejsze sankcje aniżeli te, które dopuszcza kodeks cywilny w zakresie przedłużenia czasu na ukończenie robót i otrzymanie dodatkowej zapłaty, jest nieskuteczne. Podobnie nieskuteczne jest po upływie tego terminu podnoszenie przez Zamawiającego zarzutu przedawnienia. Jak wskazał Sąd, zastrzeżenie tego typu jest niedopuszczalne. Zob. wyrok Sądu Okręgowego w Warszawie z dnia 13 lipca 2011 r., sygn. akt XXV C 701/10, dostępny na: orzeczenia.warszawa.so.gov.pl [dostęp: 20.08.2020].
} 
do klauzuli uniemożliwiło lub też przyniosło szkodę zbadaniu roszczenia w odpowiedni sposób ${ }^{10}$.

Powyżej wskazany obowiązek terminowego zgłoszenia przez wykonawcę roszczenia, zarówno czasowego, jak i finansowego wynikającego z Subklauzuli 20.1 FIDIC z 1999 r., jest jednym z najbardziej kontrowersyjnych etapów postępowania przed Komisją Rozjemczą z uwagi na zastrzeżenie terminu, w ramach którego ma nastąpić jego zgłoszenie, oraz wątpliwych skutków zaistniałych w przypadku jego upłynięcia. Spór ten praktycznie do dnia dzisiejszego nie został jednoznacznie rozstrzygnięty, gdyż zarówno w doktrynie, jak i orzecznictwie polskim funkcjonuje stanowisko mówiące o nieważności tego typu umownego postanowienia. Niemniej, pomimo wskazanego powyżej stanowiska, Sąd Najwyższy w wyroku z dnia 23 marca 2017 r. ${ }^{11}$ orzekł o dopuszczalności tego typu umownego zastrzeżenia. Pozytywnym skutkiem przyjętego przez Sąd Najwyższy rozstrzygnięcia jest umożliwienie wykonawcy skutecznego dochodzenia roszczenia na podstawie Subklauzuli 20.1 Warunków Kontraktowych FIDIC z 1999 r. ${ }^{12}$

Powyżej przywołane rozstrzygnięcie Sądu Najwyższego spotkało się z pozytywnym przyjęciem. Jak trafnie wskazuje A. Szlęzak, zastrzeganie umownych terminów zawitych, w tym terminu zgłoszenia roszczenia zgodnie z Subklauzulą 20.1 FIDIC z 1999 r., należy uznać za mieszczące się w granicy swobody umów. Jeżeli jakaś strona nie podejmuje określonych w umowie aktów staranności, to, $\mathrm{z}$ uwagi na zaniechanie w tym zakresie, jej roszczenie wygaśnie (zgodnie z treścią Subklauzuli 20.1) lub też niepowstanie ${ }^{13}$.

Nowe postanowienia FIDIC z 2017 r. w Subklauzuli 20.2.1 (zastępującej Subklauzulę 20.1 FIDIC z 1999 r.) zrównoważyły rygorystyczne skutki uchybienia 28-dniowego terminu zarówno dla wykonawcy, jak i zamawiającego. Okoliczność ta wskazuje na konieczność dochowania przez strony większej

\footnotetext{
${ }^{10}$ Zob. Warunki Kontraktu na urzadzenie i budowe z projektowaniem dla urzadzeń elektrycznych $i$ mechanicznych oraz dla robót budowlanych i inżynieryjnych projektowanych przez wykonawce, wyd. angielsko-polskie, SIDiR 2000, s. 60.

${ }^{11} \mathrm{~W}$ przedmiotowym wyroku Sąd Najwyższy wskazał, że zawarta w umowie stron Subklauzula 20.1 Warunków Kontraktowych FIDIC z 1999 r. może dotyczyć jedynie odpowiedzialności kontraktowej zamawiającego. Jej naruszenie mogło prowadzić jedynie do wygaśnięcia uprawnienia wykonawcy do żądania od zamawiającego zapłaty wynagrodzenia za roboty dodatkowe, które nie były objęte przedmiotem zawartej umowy na podstawie FIDIC z 1999 r. Zob. wyrok Sądu Najwyższego z dnia 23 marca 2017, sygn. akt V CSK 449/16, LEX nr 2297428.

${ }^{12}$ M. LESZKo, Zgłoszenie roszczeń - termin i skutki jego uptywu. Rozważania na podstawie warunków kontraktowych FIDIC w wersji z 1999 oraz z 2017 roku, [w:] Nowe warunki kontraktowe FIDIC z 2017 roku z perspektywy polskiej, ,DLA PIPER” 2018, s. 31.

${ }^{13}$ Zob. A. SZLĘZAK, Dopuszczalność zastrzegania umownych terminów zawitych. Glosa do wyroku SN z dnia 23 marca 2017 r., V CSK 449/16, „Glosa”. Prawo gospodarcze w orzecznictwie i komentarzach 2018, nr 1(174), s. 21-26.
} 
staranności w formułowaniu roszczeń już na etapie negocjowania umowy. Celem takiego działania jest uniknięcie możliwości uznania przez sąd wygaśnięcia przysługujących którejkolwiek ze stron roszczeń z przyczyn wyłącznie formalnych (czyli związanych np. z uchybieniem terminu na zgłoszenie roszczenia). Dlatego też wysoka staranność w zakresie zgłaszania roszczeń jest działaniem zasadnym i celowym niezależnie od wersji Warunków Kontraktowych, które strony przyjęły jako podstawę zawieranego kontraktu budowlanego ${ }^{14}$. Na marginesie nadmienić należy, że do chwili obecnej warunki FIDIC z 2017 r. nie zostały przetłumaczone na język polski, co w zasadzie uniemożliwia ich wykorzystanie przy realizacji inwestycji budowlanych. Taki stan rzeczy spowodowany jest m.in. potencjalnymi rozbieżnościami co do tłumaczenia postanowień FIDIC z 2017 r.

\section{POSTĘPOWANIE PRZED KOMISJĄ ROZJEMCZĄ JAKO ETAP POPRZEDZAJĄCY ARBITRAŻ}

Jednym z podstawowych sposobów a zarazem najbardziej powszechnym polubownego rozwiązania zaistniałego sporu jest rozjemstwo, co znajduje m.in. swoje odzwierciedlenie chociażby w regulacjach zawieranych pomiędzy stronami umów. Rozjemstwo należy zdefiniować, jako metodę pozwalającą na rozwiązanie sporu poprzez odwołanie się do zasad zdrowego rozsądku, uwzględniając przy tym wszystko to co słuszne i sprawiedliwe, czyli czynniki pozwalające na przyspieszenie polubownego rozwiązania zaistniałego między stronami sporu bez konieczności wchodzenia na drogę postępowania sądowego czy też arbitrażowego. Celem uniknięcia długotrwałego postępowania przed sądem powszechnym, FIDIC jako jedną z alternatyw proponuje rozjemstwo, w ramach którego strony oddają swój spór do rozstrzygnięcia przed Komisją Rozjemczą ${ }^{15}$.

Podstawą funkcjonowania Komisji Rozjemczej, jako podmiotu mającego za zadanie rozstrzygnięcie zaistniałego sporu, jest umowa stron. Działa ona tylko i wyłącznie z umocowania wynikającego z treści łączącego strony kontraktu. Jej charakter prawny jak i podstawę działania (uwzględniając mechanizm powoływania członków Komisji Rozjemczej jak i sposób procedowania) określają wyłącznie procedury FIDIC, gdyż regulacji w tym zakresie nie zawierają przepisy ustawy z dnia 17 listopada 1964 r. - Kodeks postępowania cywilnego ${ }^{16}$ czy też

\footnotetext{
${ }^{14}$ M. LeSZKo, Zgłoszenie roszczeń, s. 34.

${ }^{15} \mathrm{R}$. Stopa, Legalne uwarunkowania rozjemstwa - prawne podstawy rozjemstwa, ,Biuletyn Konsultant" 2010, nr 15, s. 18.

${ }^{16}$ Ustawa z dnia 17 listopada 1964 r. - Kodeks postępowania cywilnego, Dz.U. 2020, poz. 288, 462, 875, 956, 1017, 1086 z późn. zm.
} 
ustawy z dnia 7 lipca 1994 r. - Prawo budowlane ${ }^{17}$. Postępowanie przed Komisją należy uznać za kolejny etap polubownego rozwiązania sporów mogących powstać $\mathrm{w}$ trakcie realizacji inwestycji budowlanej, przewidzianego przez FIDIC. Komisja rozjemcza powoływana jest dopiero wtedy, gdy pomiędzy stronami nie dojdzie do porozumienia na etapie postępowania przed Inżynierem Kontraktu ${ }^{18}$.

Jeżeli spór nie został rozwiązany w toku postępowania przed Inżynierem Kontraktu, to zostaje przekazany do rozstrzygnięcia w drodze postępowania przed Komisją Rozjemczą procedującą zgodnie z Subklauzulą 20.4 FIDIC z 1999 r., która w swojej treści zawiera postanowienia w zakresie czasu trwania postępowania przed Komisją oraz formy zakończenia sporu. Nadto przepisy Subklauzuli 20.2 odnoszą się także do terminu, w jakim powinien zostać wyznaczony skład Komisji, czy też regulują kwestię związaną z obowiązkiem wzajemnego powiadamiania się stron o zamiarze skierowania sporu do Komisji zgodnie z Subklauzulą 20.4 .

Komisja Rozjemcza powoływana jest w momencie podpisania kontraktu, stanowiąc stały organ, funkcjonujący aż do zakończenia zawartej umowy ${ }^{19}$. Co istotne, każdy członek Komisji ma obowiązek bywać na placu budowy poprzez np. czynne uczestnictwo w radach budowy. Obowiązek ten zasadniczo ma na celu umożliwienie szybkiego rozwiązania sytuacji spornej, unikając przy tym jej eskalacji. Wskazuje się, że zadaniem Komisji jest rozstrzyganie wszelkiego typu konfliktów, których kierowanie do sądu powszechnego jest nieopłacalne, ponieważ Komisja składająca się ze specjalistów będzie mogła je rozpoznać niejednokrotnie szybciej, taniej czy też trafniej. Zasadnicza przewaga zarówno Komisji Rozjemczej, jak i sądu arbitrażowego od sądu powszechnego polega na tym, że rozstrzygnięcia tych instytucji mogą opierać się na zasadzie słuszności i nie muszą być zgodne z literą prawa, co umożliwia wydanie wyroku uwzględniającego okoliczności, które nie mogłyby zostać uwzględnione przez sąd powszechny. Jak wskazuje się w literaturze, powoływanie Komisji Rozjemczej do rozstrzygania sporów staje się powoli standardem na rynku budowlanym $^{20}$. Niemniej należy zasygnalizować, że w przemyśle budowlanym powszechnie stosowanym sposobem rozwiązywania sporów powstałych w trakcie

\footnotetext{
${ }^{17}$ Ustawa z dnia 7 lipca 1994 r. - Prawo budowlane, Dz.U. 2020, poz. 1333 z późn. zm.

${ }^{18}$ E. SNAKOwSKA-ESTORNINHO, Skutki prawne decyzji wydanej przez Komisję Rozjemstwa w Sporach $w$ kontraktach FIDIC, LEX el. nr 270762 [dostęp: 29.07.2020].

${ }^{19} \mathrm{Na}$ marginesie należy zaznaczyć, że Komisja Rozjemcza jako organ stały na terenie budowy, oprócz rozwiązywania sporów, zobowiązana jest także do regularnego odwiedzania terenu budowy oraz regularnych spotkań ze stronami. Zob. D. Brown, Dispute Boards - A general introduction to a Promising concept, ,,Biuletyn Konsultant” 2010, nr 15, s. 33.

${ }^{20}$ K. WoźNICKI, Rozjemstwo i arbitraż w sporach, ,Biuletyn Konsultant” 2008, nr 4, s. 39.
} 
realizacji inwestycji budowlanej jest właśnie postępowanie przed Komisją Rozjemczą $^{21}$.

Zasygnalizować należy, że postępowanie przed Komisją Rozjemczą ma wiele cech postępowania arbitrażowego. Do tych cech zaliczyć można m.in. charakter postępowania konsensualnego, czyli strony mają (podobnie jak to ma miejsce w przypadku postępowania przed sądem arbitrażowym) możliwość ustalenia zasad postępowania, członkowie Komisji muszą zachować bezstronność oraz niezależność, zaś strony muszą być traktowane w równy sposób. Finalnie nadmienić należy, o czym będzie mowa poniżej, rozstrzygnięcie Komisji Rozjemczej, tak jak wyrok sądu arbitrażowego, winno zawierać uzasadnienie ${ }^{22}$.

Odnosząc się do kosztów postępowania przed Komisją wskazać należy, że postępowanie przed nią finansowane jest przez strony w równych częściach (w przeciwieństwie do sposobu finansowania Inżyniera Kontraktu), co z kolei może wpływać pozytywnie na budowanie zaufania stron do rozstrzygnięć tego organu. Okoliczność ta uwzględniana jest już na etapie formułowania umowy o rozjemstwo, gdzie strony uwzględniają m.in. gwarancję bezstronności, fachowości członków Komisji jak i sposób płatności kosztów postępowania, w tym ich wynagrodzenia ${ }^{23}$.

\section{SKŁAD KOMISJI ROZJEMCZEJ}

Zgodnie z Subklauzulą 20.2 Komisja składa się z jednej lub trzech wykwalifikowanych osób. W przypadku, gdy strony nie uzgodnią, że skład Komisji jest jednoosobowy, wówczas jej skład winien być trzyosobowy. W takim przypadku każda ze stron mianuje jednego członka, który winien zostać zaakceptowany przez drugą stronę. Po wspólnym zaakceptowaniu wybranych członków, strony po zasięgnięciu ich opinii mianują trzeciego członka. Członek Komisji Rozjemczej wybrany w ten sposób pełni funkcję jej przewodniczącego. Niemniej jednak należy zwrócić uwagę na sytuację, w której strony, czyli Wykonawca i Zamawiający nie dojdą do porozumienia w zakresie

\footnotetext{
${ }^{21}$ E.H.W. Chan, C.K.L. Chan, M.J. Hills, Construction Industry Adjudication. A Comparative Study of International Practice, Netherlands: Kluwer Law International 2005, s. 363.

${ }^{22}$ P. PIETKIEWICZ, Wykonalność decyzji Komisji rozjemczej w umowach, „Biuletyn Konsultant” 2010, nr 15, s. 27.

${ }^{23}$ B. SOŁTYS, Koszty postępowania arbitrażowego - wybrane zagadnienia na tle sporów dotyczacych kontraktów FIDIC, „ADR. Arbitraż i Mediacja” 2014, nr 3, s. 38-39.
} 
wyboru członków składu Komisji Rozjemczej. Wówczas nominacji dokonuje wskazana przez strony w umowie o roboty budowlane osoba trzecia ${ }^{24}$.

Dodatkowo należy mieć na względzie, że przywołana powyżej Subklauzula FIDIC z 1999 r. przewiduje także możliwość powołania dodatkowego członka Komisji, który będzie mógł w razie potrzeby zastąpić jednego lub pozostałych członków. Strony mogą uzgodnić zasady, według których będzie mogło dojść do zastąpienia członków przez inną osobę. W sytuacji, w której strony nie dokonają takiego uzgodnienia, to powyższy mechanizm zastępowania członków Komisji Rozjemczej wchodzi w życie w momencie, w którym jeden z członków uchyli się od pełnienia powierzonej mu funkcji lub też nie będzie w stanie jej pełnić z powodu śmierci, niedyspozycji czy też odwołania go przez strony. Nadto każdy z członków Komisji będzie mógł zostać odwołany w drodze porozumienia stron. Subklauzula 20.2 nie przewiduje możliwości jednostronnego odwołania członka Komisji zarówno przez Zamawiającego, jak i Wykonawcę. Kadencja Komisji wygasa w momencie wydania decyzji rozstrzygającej bądź też w przypadku odwołania jej członków.

Wybór odpowiedniej liczby członków w zasadniczej mierze uzależniony jest od wielu czynników, dotyczących m.in. wielkości realizowanego kontraktu budowlanego, projektu, czasu trwania realizacji prac, jak i również zakresu kompetencji członków, które zostaną wykorzystane w toku rozwiązywanego sporu. Pomimo możliwości wyboru liczby członków Komisji, to FIDIC w swoich postanowieniach rekomenduje trójosobowy jej skład. Zazwyczaj taki skład zalecany jest w przypadku kontraktów, w których sugerowana wartość wynosi co najmniej dwa miliony dolarów. Ponadto, istotną kwestią jest także ustalenie, jaki język będzie właściwy dla procedowania przed Komisją. Dlatego też jest przyjęte, że językiem właściwym dla członków Komisji będzie język właściwy dla realizowanego kontraktu.

Odnosząc się w dalszej części do składu personalnego członków Komisji, ważnym elementem jest ustalenie kompetencji jej członków. Ma to zasadnicze znaczenie, gdyż pozwala na taki wybór specjalistów, których wiedza i doświadczenie umożliwią rozwiązanie zaistniałego sporu w sposób w pełni profesjonalny. Dlatego też przyjmuje się, że członkami Komisji powinni być co do zasady inżynierowie, specjaliści z danej branży objętej realizowanym kontraktem. Z praktycznego punktu widzenia wskazuje się, że pożądanym członkiem Komisji powinien być także prawnik jako przewodniczący (tzw. Chair man) składu rozstrzygającego.

\footnotetext{
${ }^{24}$ E. Baker, B. Mellors, S. Chalmers, A. Lavers, FIDIC Contract: Law and Practice, London: Taylor \& Francis Ltd 2009, s. 515.
} 
Ponadto, warunkiem formowania składu Komisji Rozjemczej jest także narodowość członków tej Komisji, która powinna być inna niż stron.

Subklauzula 20.2 reguluje także kwestię związaną m.in. z ustaleniem zasad wynagradzania członków Komisji Rozjemczej. Sprawę tę uzgadnia się na etapie podejmowania decyzji co do jej składu osobowego. Zgodnie zatem z brzmieniem klauzuli, każda ze stron jest odpowiedzialna za zapłatę połowy wynagrodzenia członków Komisji Rozjemczej. Niemniej, odnosząc się już do samego wynagrodzenia poszczególnych członków Komisji Rozjemczej, przyjmuje się dla stałego modelu postępowania ustalenie dla przewodniczącego Komisji wynagrodzenia wyższego aniżeli wynagrodzenie pozostałych członków Komisji. Okoliczność ta wynika przede wszystkim z większego zakresu obowiązków ciążących na przewodniczącym, polegających chociażby na prowadzeniu dodatkowych prac o charakterze administracyjnym ${ }^{25}$. Ubocznie należy nadmienić, zgodnie ze stanowiskiem prezentowanym w literaturze zagranicznej, że niejednokrotnie forma porozumienia w zakresie wynagradzania członków Komisji określa jedynie stawkę dzienną, a nie stawkę godzinową. Taki stan rzeczy może prowadzić do sytuacji, w której czas pracy przewodniczącego mierzony jest w godzinach a nie dniach. Stąd też regulacja w tym zakresie winna zostać uwzględniona przez strony w zawieranej umowie o rozstrzyganiu sporów ${ }^{26}$.

Postanowienia FIDIC odnoszą się także do sytuacji, w których ustalenie składu Komisji Rozjemczej jest niemożliwe albo znacznie utrudnione. Według Subklauzuli $20.3 \mathrm{w}$ przypadku, gdy strony nie są w stanie uzgodnić jedynego członka Komisji Rozjemczej w terminie 28 dni, zgodnie z Subklauzulą 20.2, któraś ze stron nie może mianować członka Komisji w przypadku trzyosobowego składu, strony nie są w stanie uzgodnić i wyznaczyć trzeciego członka, będącego jednocześnie przewodniczącym Komisji w terminie 28 dni, czy też strony nie mogą dokonać wyboru członka zastępującego w terminie 42 dni od dnia, w którym jedyny członek bądź jeden z trzech członków uchyla się od pełnienia powierzonej mu funkcji z powodu śmierci, niezdolności, rezygnacji czy też odwołania go, wówczas wymieniona w załączniku do oferty wyznaczająca osoba prawna lub urzędnik może, na żądanie jednej lub obu stron oraz po konsultacji z nimi, dokonać wyboru członka Komisji. Taki wybór jest ostateczny i dla stron wiążący.

\footnotetext{
${ }^{25}$ Tamże, s. 517-521.

${ }^{26}$ N.G. Bunni, The FIDIC forms of Contract, Cornwall: Blackwell Publishing 2005, s. 631.
} 


\section{ROZSTRZYGNIĘCIE KOMISJI ROZJEMCZEJ}

Celem uzyskania rozstrzygnięcia sporu powstałego w związku z realizacją kontraktu czy też robót budowlanych, strony, czyli Wykonawca lub Zamawiający, mogą skierować spór do rozwiązania przez Komisję Rozjemczą, o czym była mowa powyżej. Rozstrzygnięcie Komisji przyjmuje formę decyzji ${ }^{27}$. Regulację w tym zakresie zawiera Subklauzula 20.4.

Po skierowaniu sporu do Komisji każda ze stron zobowiązana jest do bezzwłocznego przekazania całej dokumentacji, umożliwiając komisji dostęp do placu budowy czy też urządzeń w taki sposób, aby mogła podejmować kroki zmierzające do wydania decyzji. Powinna ona zostać wydana w terminie 84 dni od dnia przekazania sporu, niemniej przepisy FIDIC z 1999 r. przewidują możliwość przedłużenia tego terminu za obopólną zgodą stron. Po przeprowadzeniu postępowania Komisja wydaje decyzję, która powinna zawierać uzasadnienie.

Wydanie decyzji uzależnione jest w zasadniczej mierze od uiszczenia przez strony stosownych opłat zgodnie z przedłożonymi przez członków Komisji fakturami. W przypadku, gdyby żadna strona nie uiściła należności, Komisja uprawniona jest do wstrzymania się z rozstrzygnięciem do dnia zapłaty. Decyzja Komisji jest wiążąca dla stron i podlega natychmiastowemu wprowadzeniu jej w życie, chyba że zostanie zaskarżona w trybie postępowania przed sądem arbitrażowym. W przypadku braku akceptacji rozstrzygnięcia przez którąkolwiek ze stron, są one zobowiązane do przekazania powiadomienia o niezadowoleniu z decyzji w terminie 28 dni od dnia otrzymania decyzji. W przypadku niezłożenia w tym terminie powiadomienia o niezadowoleniu, decyzja staje się ostateczna i wiążąca, zaś strony tracą możliwość odwołania do sądu arbitrażowego.

Na marginesie należy nadmienić, że zasadnicza różnica pomiędzy rozstrzygnięciem sądu arbitrażowego a Komisji Rozjemczej jest taka, że decyzje Komisji Rozjemczych nie są wykonywalne w takim zakresie jak wyrok sądu arbitrażowego. Wyrok sądu arbitrażowego po jego zatwierdzeniu przez sąd państwowy ma taką samą moc prawną jak wyrok sądu państwowego. Po przeprowadzeniu postępowania zatwierdzającego, wyrok sądu arbitrażowego może stanowić

\footnotetext{
${ }^{27}$ Rozstrzygnięcie Komisji Rozjemczej nie ma mocy równoważnej z wyrokiem sądu arbitrażowego. Wywiera jedynie taki skutek dla stron, jak oznaczenie przez osobę trzecią treści jej świadczenia. Rozwiązanie to znajduje swoje uzasadnienie wówczas, gdy rozstrzygnięcie sporu polega zasadniczo na ustaleniu treści zobowiązania przy jednoczesnym wymogu posiadania specjalistycznej wiedzy, zaś wystarczające jest ustalenie treści tego zobowiązania przez osobę trzecią. Nie zachodzi wówczas konieczność uzyskania tytułu egzekucyjnego. Dlatego też niewykonanie przez którąkolwiek ze stron rozstrzygnięcia Komisji Rozjemczej traktuje się na równi z niewykonaniem umowy. Zob. P. PietKiewicz, Wykonalność decyzji, s. 27.
} 
podstawę egzekucji. Takiej mocy prawnej nie mają decyzje Komisji Rozjemczej, co do których jedna ze stron złożyła „powiadomienie o swoim niezadowoleniu”. Ponadto, z uwagi na tę okoliczność, nie ma do nich zastosowania postępowanie zatwierdzające jak w przypadku wyroku sądu arbitrażowego ${ }^{28}$. O tym, że decyzja Komisji Rozjemczej nie ma charakteru prawnego równego wyrokowi sądu arbitrażowego, mówi także Subklauzula 20.4 FIDIC z 1999 r. (np. Czerwona Księga FIDIC z 1999 r.). Decyzja Komisji Rozjemczej wywołuje dla stron taki sam skutek jak decyzja Inżyniera, tzn. jest wiążąca dla stron, które są zobowiązane do jej wykonania i staje się ostateczna dopiero po upływie $28 \mathrm{dni}^{29}$.

Subklauzula 20.7 reguluje taką kwestię, gdy strony nie zastosowały się do obowiązku przesłania powiadomienia o sporze, a decyzja Komisji stała się ostateczna, czy też jedna ze stron, pomimo ciążącego na niej obowiązku zastosowania się do decyzji, tego nie uczyniła. Wówczas druga strona może skierować sprawę do arbitrażu, co nie będzie stanowiło naruszenia reguł zawartych we wcześniejszych subklauzulach. Dodać należy, że w przypadku, gdy pomiędzy stronami dojdzie do powstania sporu na tle realizowanego kontraktu budowlanego, a Komisja zakończyła swoje prace, wówczas regulacje zawarte w Subklauzulach 20.4, 20.5 nie będą miały zastosowania, a spór będzie mógł zostać skierowany bezpośrednio do arbitrażu, o czym mowa w Subklauzuli 20.8.

Nadmienić należy, że decyzje Komisji Rozjemczej nie mogą być traktowane w taki sam sposób, w jaki są traktowane wyroki sądu arbitrażowego. Gdy żadna ze stron, zgodnie z Subklauzulą 20.4 nie przedstawi drugiej powiadomienia o swoim niezadowoleniu, decyzja Komisji Rozjemczej staje się ostateczna ${ }^{30}$. Z uwagi na ostateczność decyzji i jej wiążący charakter dla każdej ze stron wynikający z zawartego kontraktu, okoliczność jej niewykonania może powodować powstanie roszczenia odszkodowawczego opartego o zarzut nienależytego wykonania umowy. Co więcej, nieprzedstawienie roszczenia przez jedną ze stron świadczy o tym, że strona ta wyraża zgodę na treść decyzji, stanowiącej rodzaj umowy zawartej pomiędzy tymi stronami ${ }^{31}$.

\footnotetext{
${ }^{28}$ P. PIETKIEwICZ, Egzekwowalność decyzji Komisji rozjemczych w umowach FIDIC, „ADR. Arbitraż i Mediacja” 2010, nr 1, s. 86.

${ }^{29}$ Tamże, s. 87-88.

${ }^{30}$ Wiążąca moc decyzji Komisji Rozjemczej może budzić poważne wątpliwości z uwagi na fakt, że podstawą funkcjonowania Komisji jest zapis umowny. Dlatego też moc wiążąca Komisji ma swoje umocowanie w łączącym strony stosunku prawnym, czyli zawartej umowie. Niejednokrotnie zdarzało się, że strona niezadowolona z rozstrzygnięcia Komisji Rozjemczej nie respektowała jej rozstrzygnięcia, a co za tym idzie - nie czuła się zobowiązana do wypełnienia jej zobowiązań. Zob. E. SNAKOWSKA-EstoRninHo, Skutki prawne decyzji, LEX nr 270762 [dostęp: 25.08.2020].

${ }^{31}$ P. PIETKIEwICZ, Egzekwowalność decyzji Komisji, s. 91.
} 


\section{ARBITRAŻ \\ W ŚWIETLE REGULACJI WARUNKÓW KONTRAKTOWYCH FIDIC}

Przed rozpoczęciem postępowania arbitrażowego strony w pierwszej kolejności powinny podjąć próbę rozwiązania sporu w drodze postępowania przed Inżynierem kontraktu i Komisją Rozjemczą. Niemniej, gdyby strony zaniechały podjęcia takiej próby, arbitraż może odbyć się po upływie 56 dni od dnia, w którym jedna ze stron przedłożyła powiadomienie o niezadowoleniu, o czym mowa w Subklauzuli 20.5 FIDIC z 1999 r.

Kwestia dotycząca trybu postępowania w drodze arbitrażu regulowana jest przez Subklauzulę 20.6., mianowicie każdy spór, który nie został rozwiązany czy to w trybie postępowania przed Komisją Rozjemczą, czy też zgodnie z Subklauzulą 20.5, a do którego wydana przez Komisję decyzja nie stała się ostateczna i wiążąca dla stron, będzie rozstrzygnięty w drodze arbitrażu międzynarodowego. Zgodnie z Subklauzulą 20.6. spór, który nie został rozwiązany na podstawie poprzedzającej Subklauzuli, będzie rozstrzygany według reguł Arbitrażu Międzynarodowej Izby Handlu (ICC) przez trzech arbitrów wyznaczonych w sposób przewidziany przez te reguły. Język postępowania zostanie ustalony według Subklauzuli 1.4 (Prawo i język).

Rozstrzyganie sporów zgodnie z regułami określonymi przez ICC nie jest przypadkowe, gdyż wynika m.in. z uwarunkowań historycznych odnoszących się chociażby do daty ich powstania. Relacja i wzajemna współpraca pomiędzy FIDIC a Międzynarodową Izbą Handlu jest widoczna zwłaszcza w przypadku procedur, które są zawarte w postanowieniach FIDIC z 1999 r., dotyczących rozstrzygania sporów. Wcześniejsze wydanie FIDIC z 1999 r., tzw. Czerwona Księga odróżniała się m.in. od brytyjskich krajowych rozwiązań poprzez przyjęcie rozstrzygania sporów zgodnie z procedurą i regulaminem Postępowania Pojednawczego i Arbitrażu przewidzianego w ICC $^{32}$. Natomiast w przypadku skierowania sporu powstałego $\mathrm{w}$ ramach realizacji inwestycji budowlanej w Polsce, strony mogą oddać spór pod rozstrzygnięcie stałego sądu arbitrażowego przy Stowarzyszeniu Inżynierów Doradców i Rzeczoznawców (dalej: SIDiR), który specjalizuje się w rozstrzyganiu sporów budowlanych, zapewniając przy tym wysoki profesjonalizm i jakość postępowania. Nadmienić należy, że arbitrzy stałego sądu arbitrażowego przy SIDiR są specjalistami z branży budowlanej, mającymi bogate doświadczenie w rozwiązywaniu tego typu sporów ${ }^{33}$.

\footnotetext{
${ }^{32}$ E. Baker, B. Mellors, S. Chalmers, A. Lavers, FIDIC Contract, s. 6-7.

${ }^{33}$ A. KĄKOLECKI, Korzystajmy z arbitrażu, ,Biuletyn Konsultant” 2015, nr 38, s. 25.
} 
Subklauzula przewiduje dla arbitra szerokie uprawnienia w zakresie wglądu w rozpatrzenia i rewizję każdego świadectwa, polecenia, opinii czy też wyceny sporządzonej przez inżyniera. Ponadto, arbiter może zapoznać się z każdą decyzją wydaną przez Komisję Rewizyjną, a która to decyzja odnosi się do sporu będącego przedmiotem postępowania. Subklauzula 20.6. przewiduje także możliwość przesłuchania Inżyniera Kontraktu, który w każdym przypadku dotyczącym danego sporu nie może zostać uznany za niezdolnego do powołania go na świadka. W toku postępowania arbitrażowego każda ze stron może powołać wnioski dowodowe nawet wówczas, gdy nie powoływano ich w postępowaniu przed Komisją Rozjemczą na etapie uzyskiwania decyzji. Należy mieć na względzie, że każda wydana przez Komisję decyzja może zostać powołana jako dowód w sprawie zawisłej przed sądem arbitrażowym. Odnosząc się stricte do postępowania przed sądem arbitrażowym wskazać należy, w ślad za regulacją zawartą w Subklauzuli 20.6, że arbitraż może zostać rozpoczęty zarówno przed, jak i po ukończeniu robót budowlanych. Możliwość prowadzenia arbitrażu w toku prowadzonych prac budowlanych nie wpływa w jakikolwiek sposób na zobowiązania stron, Inżyniera kontraktu czy też Komisji Rozjemczej.

Skutkiem wytoczenia powództwa przed sądem powszechnym z pominięciem wskazanych powyżej procedur będzie oddalenie powództwa z uwagi na jego przedwczesne wytoczenie. W takim przypadku możliwe będzie ponowne przeprowadzenie procedur przedsądowych i wszczęcie postępowania w tej samej sprawie, pozwalając na ponowne zbadanie istoty zgłoszonego roszczenia. Pełne wyczerpanie procedury polubownego rozwiązania sporu przewidzianej przez FIDIC odgrywa więc istotne znaczenie, gdyż może być traktowane jako materialnoprawna przesłanka dochodzenia roszczeń ${ }^{34}$.

\section{PODSUMOWANIE}

Przedsiębiorcy branży budowlanej coraz częściej dostrzegają pozytywne aspekty korzystania z polubownych metod rozwiązywania sporów, w tym w szczególności z rozwiązań zawartych w FIDIC. Regulacje dotyczące postępowania polubownego dają możliwość zminimalizowania potencjalnej szkody, mogącej powstać w przypadku sporu zaistniałego w trakcie realizacji inwestycji budowlanej. Podkreślić należy, że regulacje FIDIC w sposób przejrzysty ustalają

\footnotetext{
${ }^{34}$ A. OLSZEWSKI, Kontraktowe procedury rozwiązywania sporów w umowach o roboty budowlane opartych na wzorcach umownych FIDIC - w świetle prawa polskiego, „Monitor Prawniczy” 18 (2010), nr 21, s. 1206.
} 
przebieg postępowania przed Inżynierem kontraktu czy też Komisją Rozjemczą, co pozwala stronom uwzględnić czas niezbędny do rozwiązania potencjalnego sporu. Ponadto profesjonalizm podmiotów pełniących funkcje rozjemcze, na których wybór strony mają zasadniczy wpływ, stanowi gwarancję wypracowania porozumienia akceptowalnego przez wszystkie strony realizowanego kontraktu.

\section{BIBLIOGRAFIA}

ŹRÓDŁA PRAWA

Ustawa z dnia 17 listopada 1964 r. - Kodeks postępowania cywilnego, Dz.U. 2020, poz. 288, $462,875,956,1017,1086$ ze zm.

Ustawa z dnia 7 lipca 1994 r. - Prawo budowlane, Dz.U. 2020, poz. 1333 ze zm.

\section{ORZECZNICTWO}

Uchwała Sądu Najwyższego z dnia 19 maja 1969 r., sygn. akt III CZP 5/68, OSNC 1970, nr 7-8, poz. 117.

Wyrok Sądu Najwyższego z dnia 23 marca 2017, sygn. akt V CSK 449/16, LEX nr 2297428.

Wyrok Sądu Okręgowego w Warszawie z dnia 13 lipca 2011 r., sygn. akt XXV C 701/10, orzeczenia.warszawa.so.gov.pl, [dostęp: 20.08.2020].

Wyrok Sądu Okręgowego w Toruniu z dnia 12 października 2016 r., sygn. akt VI GC 99/16, LEX nr 1026.

\section{LITERATURA}

BaKer Ellis, Mellors Ben, Chalmers Scott, Lavers Anthony: FIDIC Contracts: Law and Practice, London: Taylor \& Francis Ltd. 2009.

BAŁDYGA Marcin: O Subklauzuli 20.1 Warunków Kontraktowych FIDIC, „Biuletyn Konsultant” 2013, nr 29, s. 11-13.

Brown Dan: Dispute Boards - A general introduction to a Promising concept, ,Biuletyn Konsultant" 2010, nr 15, s. 33-35.

Bunni Nael: The FIDIC forms of Contract, Blackwell Publishing, Cornwall 2005.

Chan Edwin H.W., Chan Charles K.L., Hills Martyn J.: Construction Industry Adjudication. A Comparative Study of International Practice, Netherlands: Kluwer Law International 2005.

KĄKOLECKI Andrzej: Korzystajmy z arbitrażu, ,Biuletyn Konsultant” 2015, nr 38, s. 3-4.

LESzKo Monika: Zgłoszenie roszczeń - termin i skutki jego upływu. Rozważania na podstawie warunków kontraktowych FIDIC w wersji z 1999 oraz z 2017 roku, [w:] Nowe warunki kontraktowe FIDIC z 2017 roku z perspektywy polskiej, ,DLA PIPER” 2018, s. 29-34. 
OLSZEWSKI Adam: Kontraktowe procedury rozwiązywania sporów w umowach o roboty budowlane opartych na wzorcach umownych FIDIC - w świetle prawa polskiego, „Monitor Prawniczy” 18 (2010), nr 21, s. 1205-1208.

PIETKIEwicz Paweł: Egzekwowalność decyzji Komisji rozjemczych w umowach FIDIC, „ADR. Arbitraż i Mediacja” 2010, nr 1, s. 85-91.

PIETKIEwICZ Paweł: Wykonalność decyzji Komisji rozjemczej w umowach, „Biuletyn Konsultant” 2010, nr 15, s. 26-29.

SnAKOwsKa-Estorninho Edyta: Skutki prawne decyzji wydanej przez Komisję Rozjemstwa w Sporach w kontraktach FIDIC, LEX nr 270762 [dostęp: 29.07.2020].

SoŁTYS Bogusław: Koszty postępowania arbitrażowego - wybrane zagadnienia na tle sporów dotyczących kontraktów FIDIC, „ADR. Arbitraż i Mediacja” 2014, nr 3, s. 37-45.

StоPA Ryszard: Legalne uwarunkowania rozjemstwa - prawne podstawy rozjemstwa, ,Biuletyn Konsultant" 2010, nr 15, s. 22-24.

SZLĘZAK Andrzej: Dopuszczalność zastrzegania umownych terminów zawitych. Glosa do wyroku SN z dnia 23 marca 2017 r., V CSK 449/16. „Glosa”. Prawo gospodarcze w orzecznictwie i komentarzach 2018, nr 1(174), s. 21-26.

VINK Enrico: FIDIC and the use of Dispute. Adjudication Boards, ,Biuletyn Konsultant” 2010, nr 15, s. 30-32.

Warunki Kontraktu na urządzenie i budowę z projektowaniem dla urządzeń elektrycznych i mechanicznych oraz dla robót budowlanych i inżynieryjnych projektowanych przez wykonawcę, wyd. angielsko-polskie, SIDiR 2000.

WiKTOROwSKA EWA: Zgodność warunków kontraktowych FIDIC z prawem polskim, „Biuletyn Konsultant" 2010, nr 15, s. 10-12.

WoźNICKI Krzysztof: Rozjemstwo i arbitraż w sporach, „Biuletyn Konsultant” 2008, nr 4, s. 39-41.

WYSOCZAŃSKI Hubert: Prawo do zmiany oraz polecenie zmiany treści umowy o roboty budowlane w świetle warunków FIDIC, Warszawa: Wydawnictwo C.H. Beck 2017.

INNE ŹRÓDŁA

http://www.rynekinfrastruktury.pl/wiadomosci/drogi/powrot-arbitrazu-do-rozstrzygania-sporoww-budownictwie-drogowym-58784.html [dostęp: 20.08.2020].

\section{PROCEDURA POSTĘPOWANIA POLUBOWNEGO W WARUNKACH KONTRAKTOWYCH FIDIC}

\section{Streszczenie}

Celem artykułu jest przybliżenie procedury polubownego rozwiązania sporu zawartej w Warunkach Kontraktowych FIDIC (dalej: FIDIC). Przedsiębiorcy z branży budowlanej coraz częściej dostrzegają pozytywne aspekty stosowania polubownych metod rozwiązywania sporów, w szczególności rozwiązań przewidzianych przez FIDIC. Regulacje w nim zawarte, a dotyczące postępowania polubownego, pozwalają zminimalizować potencjalne szkody, jakie mogą powstać w przypadku sporu wynikłego w trakcie realizacji inwestycji budowlanej. FIDIC w przejrzysty sposób określa przebieg 
postępowania przed Inżynierem kontraktu lub Komisją Rozjemczą, co pozwala stronom na uwzględnienie czasu niezbędnego do rozstrzygnięcia potencjalnego sporu. Ponadto profesjonalizm podmiotów pełniących funkcje arbitrażowe jest gwarancją osiągnięcia porozumienia akceptowalnego dla wszystkich stron kontraktu.

Słowa kluczowe: ADR; prawo budowlane

\title{
THE CONCILIATORY PROCEDURE \\ IN THE FIDIC CONDITIONS OF CONTRACT
}

\begin{abstract}
Summary
The aim of the article is to present the procedure for amicable settlement of the dispute contained in the FIDIC Conditions of Contract, hereinafter FIDIC. Entrepreneurs in the construction industry more and more often see the positive aspects of using amicable dispute resolution methods, in particular the solutions contained in FIDIC. The regulations on amicable settlement contained in the FIDIC make it possible to minimize the potential damage that may arise in the event of a dispute arising during the implementation of a construction investment. It should be emphasized that FIDIC transparently determines the course of proceedings before the Contract Engineer or the Conciliation Committee, which allows the parties to take into account the time necessary to resolve a potential dispute. In addition, the professionalism of entities performing arbitration functions is a guarantee of reaching an agreement acceptable to all parties to the contract.
\end{abstract}

Key words: ADR; construction law 